with much greater financial support from the western world. Understanding Climate Change Adaptation not only supports the plea by these countries, it shows where the money, well spent, could make a big difference.

Published online: 11 June 2009 doi:10.1038/climate.2009.58
Mason Inman

Mason Inman is a freelance science writer based in Karachi, Pakistan.

e-mail:mi@masonmade.com

\title{
A third way
}

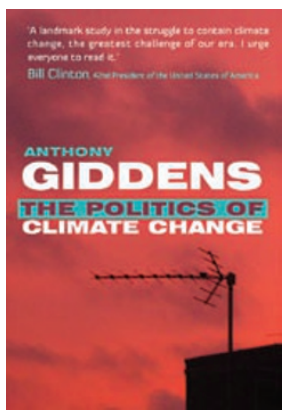

THE POLITICS OF CLIMATE CHANGE BY ANTHONY GIDDENS

\section{New philosophies on climate policy are well and good, but to be meaningful they must be translated into concrete policy options.}

Though a widely respected and prolific sociologist, Anthony Giddens is best known as the brains behind the 'thirdway' politics of the United Kingdom's New Labour movement in the late 1990s, during which he became something of a guru to former Prime Minister Tony Blair. Giddens sought to forge a new kind of politics that moved beyond the traditional debates of the political left and right. In his latest book, The Politics of Climate Change, Giddens applies his third-way thinking and considerable intellect to climate change, to generally good effect.

As a philosophical treatise, The Politics of Climate Change is excellent and in places even brilliant. Giddens is not shy of offering up perspectives sure to provoke the dominant climate policy intelligentsia. Among his heresies, he tells us that "skeptics do deserve and must receive a hearing"; and that "tackling global warming has nothing to do with saving the earth". He dismisses popularized phrases such as 'sustainable development', which he calls a "slogan, rather than an analytical concept". Similarly, he rejects the precautionary principle - typically characterized as 'better safe than sorry' - arguing that "it can be used to justify completely opposite courses of action". For example, it can give good reason for mitigating expected climate change, but equally, if the greater fear is harming economic growth, it can be used to validate inaction.

Giddens is also quite clear in his evaluation of existing policies. "There is no nation that gets even close to what might be regarded as an effective performance in terms of reduction of greenhouse gases," he writes. Taking the UK as an example, he is rightfully sceptical of the ability of the Climate Change and Energy Acts to deliver on promised emissions reductions, and he is similarly justified in noting the absence of adaptation planning from existing policy.

Having largely dismissed the rhetoric of targets and timetables that has come to dominate climate policy discussions, Giddens then moves on to promoting his own perspective. Here the book is far less satisfactory, resorting to wishy-washy recommendations and generic exhortation. For instance, he contends that "climate change should be lifted out of a right-left context, where it has no place" and says "it is up to the government to move toward a thorough clean-out of anti-environmental subsidies" without defining how either would be achieved in practice.

Many of Giddens's recommendations have a frustrating impartiality about them such that it is nearly impossible to divine his exact stance on the issues. He argues, for example, that successful adaptation requires that we "specify what the effects of global warming will be" but that it should also be flexible because "it isn't normally possible to predict in detail what will have to be confronted and when". A preponderance of such seemingly contradictory statements undercuts the prescriptive value of the book.

The book is also marred by an unacceptable number of mistakes in the details of climate policy and science. While these will probably be glossed over by the layman, they sit like an uncomfortable stone in the shoe of an expert reader. Among these are Giddens's claim that the Intergovernmental Panel on Climate Change identified a most-probable scenario for the future climate, and his assertion that El Niño events may act to moderate human-induced warming.

Perhaps more discomforting is the apparent moment of academic hubris when Giddens takes a well-known phenomenon - that people do not act on an incrementally growing threat until it becomes visible, by which stage action may be too late - and names it "the Giddens paradox". In climate change circles this concept, which is not in fact a paradox, has been cited in the literature for decades. If there is a "Giddens paradox" to be found in this book it lies in the stark contrast between the author's compelling and sensible thirdway philosophy on climate policy and his frustrating inability to translate that philosophy into concrete policy options. Overcoming that paradox is what will lead to actual progress on climate policy.

But make no mistake: overall, Giddens's book is valuable in setting forth a picture of climate policy distinctly different from that found in conventional circles, namely the political left and right. We are in desperate need of a third way. By legitimizing policy discussions other than the stale approaches that now dominate the debate, Giddens moves us a step closer to realizing a viable alternative.

Published online: 18 June 2009

doi:10.1038/climate.2009.61

\section{Roger A. Pielke}

Roger A. Pielke, Jr is a professor in the Environmental Studies Program and a fellow of the Cooperative Institute for Research in Environmental Sciences at the University of Boulder, Colorado. e-mail:pielke@colorado.edu. 